\title{
Governing climate change for a just city: challenges and lessons from Maputo, Mozambique
}

\author{
Vanesa Castán Broto ${ }^{\mathrm{a} *}$, Bridget Oballa ${ }^{\mathrm{b}}$ and Paulo Junior ${ }^{\mathrm{c}}$ \\ ${ }^{a}$ Development and Planning Unit, UCL, London, UK; ${ }^{b} U N$-Habitat, Nairobi, Kenya; \\ ${ }^{c} U N-H a b i t a t$, Maputo, Mozambique
}

\begin{abstract}
As new forms of governance for climate change emerge in African cities, will they enable emancipatory and socially progressive transformations or will they exacerbate existing inequality, poverty and vulnerability patterns? This paper presents one of the case studies developed by UN-Habitat Cities and Climate Change Initiative in Maputo, Mozambique. The case analyses first, the production of urban vulnerabilities under climate change, and second, the existing governance arrangements for climate change in the city. Building on the lessons of the case study, the paper argues that to ensure that new forms of climate change governance lead to socially and environmentally just outcomes climate change interventions should, at least, meet two conditions: first, they should consider the close interactions between social and ecological elements and, specially, how patterns of urban inequality interact with environmental factors; second, they should recognise the opportunities in African cities through a broad notion of governance that looks beyond the government as the sole agent of urban change.
\end{abstract}

Keywords: urban vulnerability; climate change governance; urban inequality; Mozambique

\section{Introduction}

Empirical evidence from different parts of the world suggests that climate change actions are often associated with governance innovations for sustainable urban development (Mieg 2012). Many policy innovations have been reactive, emerging from experts' and policy-makers' responses to new low carbon technologies and eco-city designs and new financial mechanisms associated with international agreements. At the city level, some local governments - often supported by city networks such as ICLEI or the C40 group - have sought to develop plans and interventions which either adapt national adaptation plans at the local scale or take advantage from the emerging opportunities at the local level to respond to the "urgent demands" of climate change (Bulkeley and Betsill 2003, Davies 2005, Romero Lankao 2007, Kern and Bulkeley 2009).

While these responses are important (both in terms of showing what is effective for climate change and its impact), discussions focusing on policy innovations may fail to recognise that governance innovations for climate change also emerge outside traditional spheres of government and policy-making. Multiple ad hoc innovations appear in a variety of settings and are led by a heterogeneous array of actors, sometimes forming unlikely alliances between public, private and civil society actors who may perform roles beyond what is considered their realm of action. This trend suggests that experimentation

*Corresponding author. Email: v.castanbroto@ucl.ac.uk 
is a key aspect of climate change governance, both in terms of emphasising the open-ended nature of these interventions and their purposive character (Bulkeley and Castán Broto 2013). In this respect, these experiments are associated with a sense of urgency in terms of responding to climate change challenges (WB 2010), and also, they emerge from a growing dissatisfaction with the responses provided from within formalised forums of knowledge and government, such as the IPCC, the Conference of Parties and the different spheres of government that operate in each country (Hoffman 2011).

The normative character of climate change experiments highlights their emphasis on creating transformative actions towards socially, economically and environmentally sustainable societies. Despite these broader transformative aspirations, experiments emerge within bounded spaces over which a limited group of action can intervene (Brown and Vergragt 2008). Often, anticipating and managing outcomes is beyond the boundary of the experiment itself (Bulkeley et al. 2011). Moreover, the role of climate change experiments in the city is ambiguous. Their ambiguity is partly related to the empirical realisation that scaling up climate change experiments involves a process of redefinition of the experiment that may bring it beyond its initial concerns. In every city, the potential of a climate change experiment to deliver effective action in a socially and environmentally just manner will be determined by the context of urbanisation in which the experiment occurs. This is not only because climate change experiments may remain limited to bounded scales, benefiting only those who promote them, but also because they may act to reproduce or even reinforce existing social and environmental injustices. Understanding climate change governance requires, thus, a sustained inquiry into what types of action are possible and what are their consequences.

African cities are incredibly diverse. Yet, they are often assumed to be similar in their unmanageability and lack of capacity of action, a trend that overlooks the capacity of people living in these cities to develop creative responses to manage their situation (Robinson 2006). Empirical evidence shows, first, that African cities have their specific urbanisation and spatial patterns (Doan and Oduro 2011), and second, that numerous forms of action, from the most formalised to the ad hoc intervention shape life in African cities and enable particular modes of living (Simone 2010). In the context of climate change, African cities are misconstrued as passive victims where external intervention is needed. Yet, there is evidence that action for climate change - even if experimental - is already taking place in African cities. How this is taking place and with what consequences is not yet understood.

Because of the complexity and context-specificity of urban issues in each city, urban questions are best approached from a case-study perspective. In this vein, the Cities and Climate Change Initiative (CCCI) of UN-Habitat engaged with a set of case studies through which to explore how to build capacities and enable effective action for climate change. One of the cases studied is Maputo, Mozambique, a unique city in terms of the interaction of historical patterns of urban development, the growing vulnerability to climate change risks and the emergence of new patterns of development. Experimental actions are starting to emerge in Maputo which address climate change directly or indirectly. Can we anticipate, after examining the evidence from the case study developed by the CCCI, the specific conditions that climate change experiments should meet a priori to ensure that they lead to socially and environmentally just actions in Maputo?

Although these questions go beyond the original remit of the CCCI, they seek to evaluate the existing climate change vulnerabilities and governance opportunities highlighted in the city diagnosis, showing some necessary conditions that climate change experiments should aspire to, in order to ensure progressive outcomes. The diagnosis of the CCCI 
case study raises two hypotheses about two such conditions which urban climate change experiments should meet if their outcomes are to be progressive. First, climate change experiments need to make explicit the socio-ecological relations that determine urban interventions. This means bringing to the fore the complex web of interactions which shape cities, including social institutions, culture, economic structure, resource availability and environmental risks. Second, climate change experiments should emphasise the city as a site of opportunities where citizens, rather than being helpless, hapless victims, are active agents that take creative initiatives to address both climate change and urban development in different ways and at different scales. While local governments continue to play a key role in leading urban action for climate change, private actors may also foster initiatives both in isolation and in partnership with local governments.

The case study builds upon a critical review of empirical work made by CCCI in Maputo, together with a comprehensive survey of current academic and policy literature about local governance and sustainable development in Maputo. The original work reviewed used various sources including unstructured interviews with institutional representatives at the local and national level, policy review, analysis of satellite images and an exploratory survey among communities. The insights of the case study are, first, the socio-ecological relations explicit in the context of climate change and, second, the opportunities opening up in the current governance map of Maputo, taking into consideration the context of urban development, the history of diverse institutions intervening in local governance and the multiple strategies of resource and risk management which emerge within the everyday lives of citizens. Before presenting the case study, a brief theoretical discussion of the hypotheses above is presented in the next section, linking the argument with urban political ecology debates. The final discussion returns to the theoretical argument in the light of the case study, concluding that without empirical evidence about how climate change experiments unfold in practice we have little means to assess their eventual outcomes. Thus, the two hypotheses outlined above suggest factors which are necessary but not sufficient to ensure that action for climate change in the city is environmental and socially just.

\section{Urban social natures, governance opportunities and climate change}

As new forms of governance for climate change emerge in African cities, will they enable emancipatory and socially progressive transformations or will they exacerbate existing inequality, poverty and vulnerability patterns? This paper argues that to ensure new forms of climate change governance lead to socially and environmentally just outcomes, climate change innovation should at least meet two conditions: first, they should consider the close interactions between social and ecological elements and specially, how patterns of urban inequality interact with environmental factors; second, they should recognise the opportunities in African cities through a broad notion of governance that looks beyond the government as the sole agent of urban change (for climate change or otherwise). Each of these conditions is explored in turn in the following sections.

\section{Socio-ecological interactions in cities in climate change}

Political ecologists have examined environmental struggles with attention to the actors intervening in such struggles, and particularly, critically analysing who benefits from the existing state of affairs (Blaikie and Brookfield 1987). In the exploration of the mechanisms whereby particular forms of authority over natural resources and environmental processes 
are enacted and reproduced, political ecologists highlight the importance of knowledge production processes in the generation of expectations and alternatives which enable actions to manage environmental change (Forsyth 2003). The question of knowledge production emphasises that any form of authority over social or natural worlds depends on the production and management of suitable representations of reality (Jasanoff 2006). These representations rely on the assumption that all things social, and all things natural belong to separate realms, an assumption which is deeply embedded in modern discourses of science, technology and management (Latour 1993, 2005). When dealing with environmental crises, labelling them as "natural" and ignoring how they unfold in specific social contexts "is itself a dangerous form of representation which erases the very political nature of environmental crises, yet may coincidentally produce other sorts of politized nature" (Peet et al. 2011, p. 36).

In an urban context, political ecology has highlighted the difficulties to sustain a strict separation between the social and the natural or the ecological. Instead, the city is portrayed as a fundamental site of nature transformation (Desfor and Keil 2004, Kaika 2006). Socionatural relations characterise the city as an ensemble of multiple components, which depend on ecological cycles, political institutions and economic constraints, social interaction and technological transformations (Heynen et al. 2006). This also emphasises the relational nature of cities, that is, the notion that humans, built environments, technologies and practices in the city can only be understood in relation to each other (Graham and Healey 1999). Thus, cities can be described as socio-natures produced through a historical process in which social relations and discourses interact with material processes (Swyngedouw 2004).

Climate change highlights the planetary character of the ecological crisis (Peet et al. 2011). In the context of global environmental governance, calls for urgent action and evidence-led decision-making reinforce the perceived boundaries between the social and the natural world. International and national policies have often focused on finding technological solutions which do not acknowledge the political nature of climate change debates (Lorenzoni et al. 2007). At the city level, research and policy efforts have emphasised the institutional barriers and opportunities for climate change and studied how to build local capacity, but often at the expense of overlooking the material and ecological dimensions of climate change interventions (Bulkeley 2010). The diagnosis is that despite the multiplication of efforts for climate change in cities, many of these remain a discursive exercise with limited impacts on transforming the materiality of the city (Betsill and Bulkeley 2007, Bulkeley 2010). An approach concerned with the production of urban socio-natures through experimentation will engage both with the politics of climate change action and with the material aspects of ecological and technological transformations.

\section{Opportunities for climate change governance in cities}

A sense of opportunity to address climate change in cities has grown out of multiple actions in policy and research. First, local governments in cities, often through their mayors, have shown leadership in undertaking climate change action, for example, with the development of landmark city climate change plans in cities like NY, Toronto, Mexico City, Cape Town and others. Second, international city networks, such as ICLEI or the C40, and international organisations, such as UN-Habitat and the World Bank, have turned their attention to cities as sites where climate change can be addressed, developing institutional and financial tools to address this challenge. Third, private and civil society actors have shown their ability to intervene in climate change governance (Biermann and Pattberg 2008). 
An analytical approach to municipal governance has revealed four discrete modes of governance through which local governments intervene in directing and achieving climate change action: self-governing refers to the municipal action directed at regulating its own operation; regulation refers to the traditional operation of the state through mandates and planning law; provision refers to interventions in the delivery of services and resources; and enabling refers to additional activities that support actions by other actors, through partnerships, information provision, incentives and other arrangements (Bulkeley and Kern 2006, Kern and Alber 2008, Bulkeley et al. 2009). Enabling constitutes a mode of governance through which municipal governments can reach further spheres of influence involving actors beyond the state. What this suggests is that municipal authorities themselves are moving beyond traditional understandings of how the governance of environmental change in the city, finding ways to cooperate with other actors in addressing the challenge.

Partnerships and other methods of cooperation for environmental management are becoming paramount, not only in terms of managing resources and services, but also to advance institutional and technological innovations for climate change. These ideas build upon established debates on cooperative environmental management regimes, processes of discursive consensus formation to enable collaborative and practically oriented agreements to deal with environmental issues (Glasbergen 1998). Cooperative environmental management regimes seek to address explicitly the plurality of values around the environment. This body of theory has traditionally identified two types of cooperative environmental management regimes: the public-private partnerships and partnerships between state and communities that enable community-based natural resource management (Plummer and FitzGibbon 2004). However, detailed studies of partnerships in the context of climate change demonstrate that the nature of partnerships and the actors intervening has diversified (Forsyth 2005, 2007).

In cities, multiple actors experiment not only with new technologies, designs and management techniques but also with new forms of institutional development in which established roles are under continuous negotiation. These findings suggest that the landscape of governance is increasingly more complex and that more research may be needed to understand the practical implications of these changes and the extent to which action delivered through new institutional agreements is progressive or it is open to appropriation by particular actors. These observations also suggest that there are opportunities in unexpected forms of intervention and unexpected places. Thus, any action for climate change in African cities should be directed towards understanding the development and impact of existing initiatives in the city, recognising the potential of multiple actors beyond the state to take meaningful and progressive action.

\section{Climate change in Maputo: lessons from UN-Habitat CCCI}

Climate change impacts and actions need to be understood within their overall context of urbanisation and socio-economic development. In Maputo, Mozambique, this means, for example, understanding the dynamics of the post-conflict boom and the bumps and highs in the road to recovery. The Civil War started in 1977, two years after gaining independence from Portugal, when the ruling party, the Marxist-Leninist Liberation Front of Mozambique (FRELIMO; Portuguese: Frente de Libertação de Moçambique) was violently opposed by the anti-communist Mozambican National Resistance (RENAMO; Portuguese: Resistência Nacional Moçambicana) supported first by Rhodesia and later by South Africa. The war had devastating effects in the Mozambican society, not only because millions of people died or were displaced, but also because the war hindered the consolidation of 
the state after independence and fostered a chronic economic crisis (Sidaway and Power 1995) whose consequences can be felt today.

After the ceasefire in 1992 and turning to democracy, the FRELIMO party won consecutive presidential elections in 1994, 1999 and 2004, although amidst calls for greater transparency. Since the end of the war, the economy in Mozambique has improved significantly, but the country is still extremely aid-dependent. The annual gross domestic product per capita in Mozambique was USD349 in 2006, one of the lowest in the world; however, in the last decade, the country has shown an average annual economic growth rate of about eight per cent (UNDP 2007). The country Human Development Index has increased from 0.413 in 2002 to 0.466 in 2007 (UNDP 2007). Today, agriculture is the main economic activity of the country, and most of the workforce relies on subsistence agriculture, especially in rural areas, with considerable exposition to weather-induced risks such as floods and droughts.

According to the official statistics and projections of the United Nations Department of Economic and Social Affairs, the proportion of urban population in Mozambique will be greater than the average in sub-Saharan Africa by the next decade (UNDESA 2007). The city of Maputo mediates the provision of aid and aid inflows and has a higher average income than the rest of the country but also experiences growing inequality (Brück and Broeck 2005). With an estimated population of 1.1 million, according to the definitive data of the 2007 official population census (INE 2012), the city is sharply divided between "the cement city" (the city centre which corresponds to the old colonial centre) and "the bairros" (neighbourhoods in the surrounding areas hosting the majority of people living in largely unserviced and congested areas). Bairros host the bulk of the labour force and provide the basis for the city economy.

The city of Maputo is exposed to climate-change-related vulnerabilities due to both its geographical location and its reliance on resources from other parts of the country, particularly in terms of food security. The following section explains that vulnerabilities to extreme weather events are exacerbated by the prevalence of poverty and the growing inequality in the city. After that, a further empirical section explores the opportunities for climate change governance emerging in the context of urban development in Maputo. Since 1997 Mozambique has gone through a process of decentralisation, ratified with local elections held in 1998 and in 2003. While the first mandate of local authorities was hindered by the unclear distribution of competences, lack of resources and institutional capacity, since 2004 local governments have been playing a key role in deepening democracy values in the Mozambican society and providing services to citizens. Although the existing climate change governance map in Maputo is fraught with challenges and difficulties, recent experiences in local service provision and participatory budgeting suggest that the decentralisation process is opening up significant opportunities for addressing the socioecological consequences of climate change in the city.

\section{The socio-ecological production of climate change vulnerability in Maputo}

Mozambique is an elongated country with a land area of $784,090 \mathrm{~km}^{2}$ and a coastal line of $2,515 \mathrm{~km} ; 17,500 \mathrm{~km}^{2}$ of the land is under water. Given its geographic location, the country is highly vulnerable to natural disasters, particularly those of hydro-meteorological origin (such as floods, drought and cyclones). Maputo is located at the extreme south of the country and covers an area of $300 \mathrm{~km}^{2}$. The city is part of an interconnected metropolitan system, Greater Maputo, including the municipalities of Maputo and Matola and the Marracuene District, with a fluctuating population of $2-2.5$ million inhabitants. Facing the 
Indian Ocean, Maputo is highly vulnerable to the effects of climate change. It is also the most densely populated urban area in Mozambique. The rising sea level has resulted in salty intrusion, impacting on agricultural activities and contributing to urban poverty. Further sea level rises will result in flooding of the lowest topographical areas, which are also the most populated. A noticeable reduction of sand strips on the beaches due to the continuous movement of the sea, results in coastal erosion problems. In Maputo, the main hazards associated with climate change will be temperature increases, extreme events related to precipitation and sea level rise.

According to the IPCC report of 2007, a trend of increased temperature has been observed in Mozambique (IPCC 2007). Global average precipitation will increase in warmer climates because the increase in evaporation leads to an increase in precipitation (Thow and de Blois 2008). Both increases in temperature and average precipitation will exacerbate the already high incidence of extreme events in Mozambique. During the last 25 years, Mozambique has suffered from an uninterrupted sequence of drought and floods which negatively affected the country's social and economic development. The most severe drought periods were recorded in 1981-1984, 1991-1992 and 1994-1995; while floods were observed in 1977-1978, 1985, 1988, 1999-2000 and more recently in 2007-2008. Floods are often magnified by cyclones. Since 1970, Mozambique has been hit by 34 significant cyclones or tropical depressions and 5 major flood events (2000, 2001, 2007 and 2008 and most recently in early 2012 following tropical cyclones from the Indian coast). In particular, the number of recorded cyclones during the 19992000 wet seasons was extraordinarily high and flooding had terrible consequences. During the months of February to March 2000, a combination of torrential rains and tropical cyclones caused the most devastating floods in the history of Mozambique killing 700 people and producing damages worth 600 million dollars (Kundzewicz et al. 2002, McBean and Henstra 2003).

Figure 1 illustrates the current land use in the city. Areas subject to flooding are highlighted in dark blue. Some of these areas coincide with the coastal strip and some affect the oldest established bairros in the middle of the city, such as Mafalala, Luis Cabral, Chamanculo and Xipamanine. Figure 2 provides an overview of the bairros which are most frequently flooded. Some of these neighbourhoods were still flooded 4 months after the disastrous rains of 6-8 February 2000, while today they are almost completely developed (MMC, UN-Habitat and Agriconsulting 2012).

The Intergovernmental Panel on Climate Change warned that sea levels could rise by tens of centimetres this century, making coastal populations more vulnerable to flooding and storm surges. It also predicted more intense tropical cyclones. The predicted sea level rise related to global warming will result in flooding of the lowest topographical areas of Maputo, which are the most populated. This prediction is also supported by the Mozambique National Adaptation Program of Action (MICOA 2007). A study of the changes recorded in the Maputo Bay during the Holocene period highlighted the important effects of sea level rise since 8000 years BC (Mussa et al. 2003). Flood-prone areas due to heavy rainfall and sea level rise are approximately $16 \%$ of administrative area of the Maputo Municipality, Katembe and Inhaca districts excluded (MMC, UN-Habitat and Agriconsulting 2012). Figure 3 illustrates the impact on infrastructure of an extreme event linked to climate change. It shows the current impact of sea level rise effect in Marginal Avenue in Maputo city. Although the avenue has been recently rehabilitated, no protection barriers have been installed yet. Further, the city's three islands located a few kilometres from the coast show clear evidence of climate change effects which include the disappearance of mangroves, degradation of water quality in wells, desertification, 


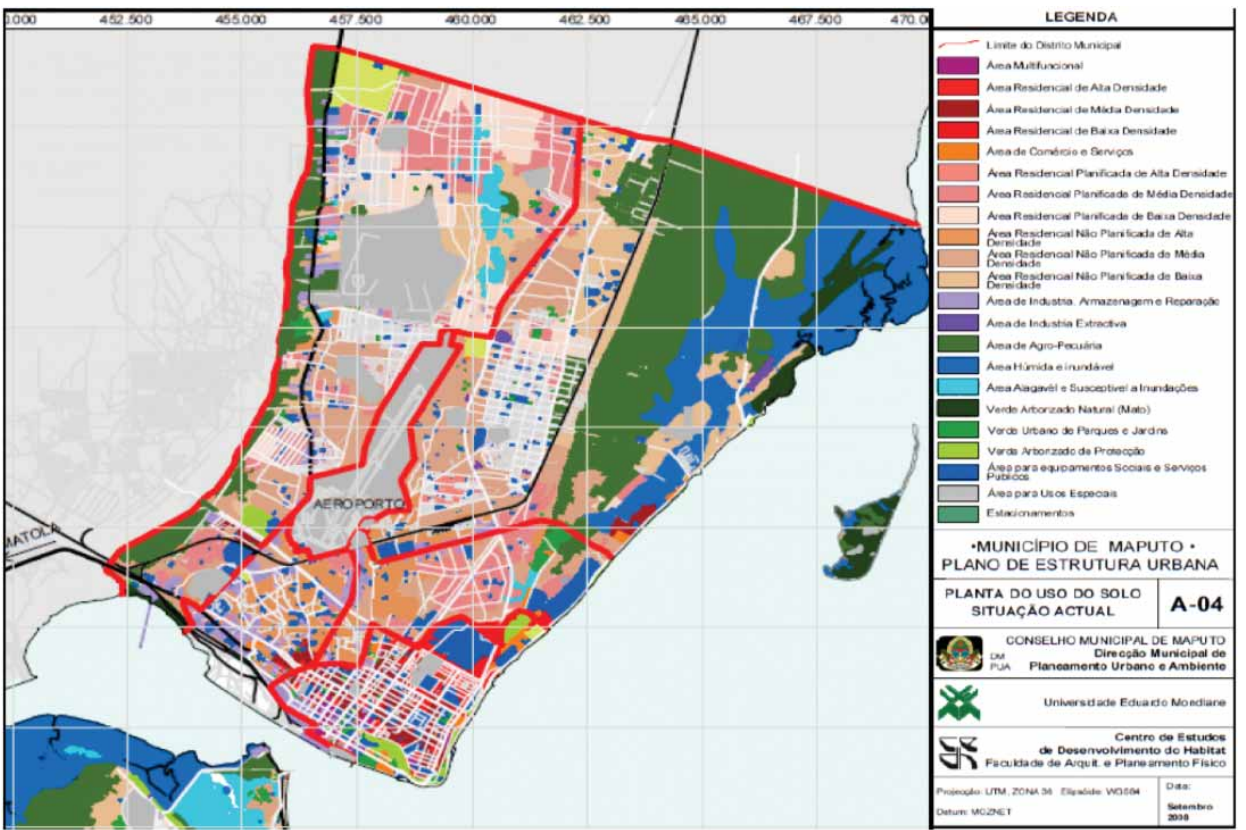

Figure 1. (Colour online) Current land use map of Maputo city. Source: Adapted from PEUMM, 2008.

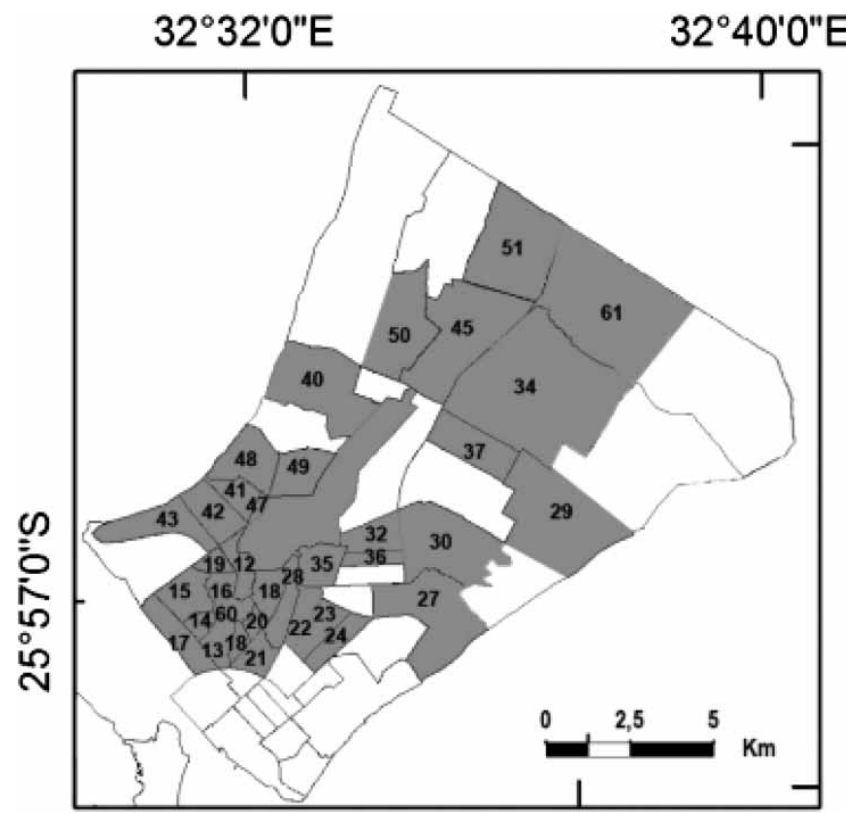

Figure 2. Bairros frequently flooded.

Source: INGC CENOE. 


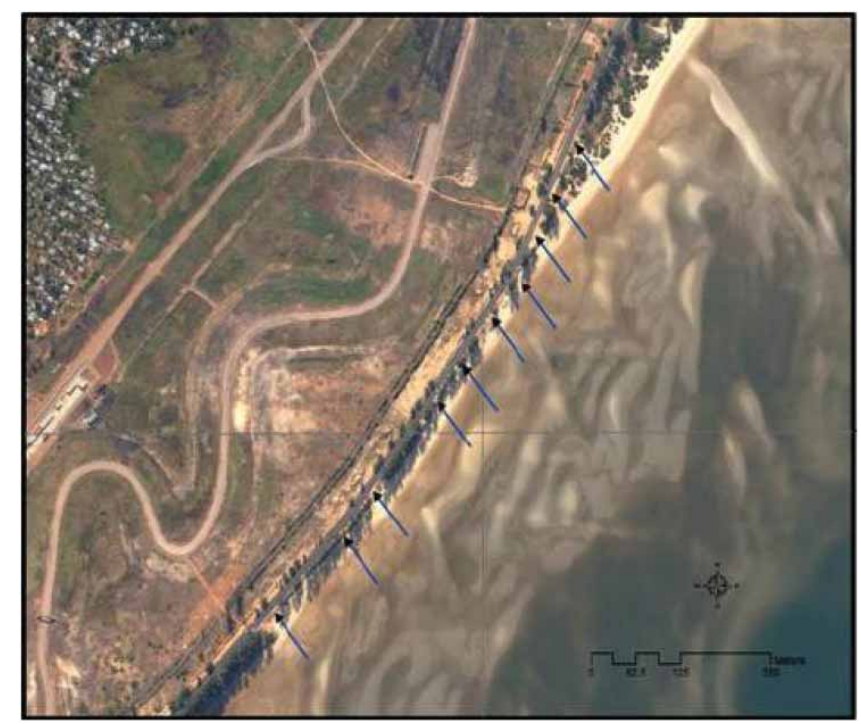

Figure 3. Points of Marginal Avenue susceptible to be affected by the erosion processes linked to the sea level rise effect.

Source: UN-Habitat CCCI.

exposure of sand dunes, worsening wind erosion, loss of coastline and reduction of arable land for domestic agriculture.

In an urban context, such impacts need to be linked to the consequences on the city's systems of service provision (e.g. water, waste, energy, transport) as well as buildings, trees and public spaces. Table 1 provides a summary of linkages between the impacts of climate change and the different urban sectors and areas in Maputo city. In addition to infrastructure damages, the table highlights additional impacts such as increased pollution, impacts on food security and an increase in vector-borne diseases. The city of Maputo is already exposed to climate change hazards, but further development, fostered by existing population growth and incoming migration is likely to exacerbate these problems.

The IPCC defines vulnerability as "the degree to which a system is susceptible to, or unable to cope with adverse effects of climate change, including climate variability and extremes" (IPCC 2007, Box 1). This highlights that vulnerability is a function of the character, magnitude and rate of climate-related changes, the system's sensitivity and its adaptive capacity. Both sensitivity and adaptive capacity are related to the ability of different actors to react to these hazards, whether this is to prevent them or to manage them. Thinking about adaptive capacity is crucial to recognise that human and natural systems cannot be treated independently (Folke et al. 2002). Moreover, the need to understand how adaptive strategies are deployed at different scales requires considering not only institutional responses but also the responses coming from a variety of private and civil society action, the public and community (Smit and Wandel 2006).

In the case of Maputo, poverty and inequality influence the adaptive capacity of the city. Table 2 shows how the population of the capital city is changing in different areas according to the data retrieved from the population census undertaken in 2007 (only Districts 1 and 2 have reduced their population). Approximately 54\% of Maputo city's residents live below the poverty line of $\$ 1.50$ per day and $70 \%$ live in informal settlements. The Multidimensional Poverty Index (MPI) is an index of acute multidimensional poverty that measures 
Table 1. Sectors and areas of Maputo city vulnerable to extreme events related to climate change.

\begin{tabular}{|c|c|c|}
\hline Sector or area & $\begin{array}{c}\text { Climate change-related } \\
\text { event }\end{array}$ & Impact or produced effect \\
\hline \multirow[t]{7}{*}{$\begin{array}{l}\text { Coastal zone and } \\
\text { ecosystems }\end{array}$} & Tropical cyclones & $\begin{array}{l}\text { Damage to coastal infrastructure, dunes, } \\
\text { beaches and other natural features }\end{array}$ \\
\hline & $\begin{array}{l}\text { Sea level rise and storm } \\
\text { flow }\end{array}$ & $\begin{array}{l}\text { Increased erosion or damage to coastal } \\
\text { infrastructure, dunes, beaches, and other } \\
\text { natural features }\end{array}$ \\
\hline & & $\begin{array}{l}\text { Loss of coastal wetlands and other coastal } \\
\text { habitats }\end{array}$ \\
\hline & & $\begin{array}{l}\text { Increased costs for maintenance and } \\
\text { expansion of coastal erosion control } \\
\text { (natural or man-made) }\end{array}$ \\
\hline & & Saltwater intrusion into coastal aquifers \\
\hline & & $\begin{array}{l}\text { Increased risk of pollution from coastal } \\
\text { hazardous waste sites }\end{array}$ \\
\hline & & Reduced effectiveness of sea walls \\
\hline \multirow[t]{2}{*}{ Transportation system } & Variations of temperature & Increased road surface and bridges damage \\
\hline & and heavy precipitation & $\begin{array}{l}\text { Increased maintenance requirements for } \\
\text { roadside/pavement }\end{array}$ \\
\hline \multirow{3}{*}{$\begin{array}{l}\text { Wetlands and urban } \\
\text { agriculture }\end{array}$} & Heavy precipitation & Increased risk of flooding \\
\hline & Dry season & $\begin{array}{l}\text { Crop failures, water scarcity, drying of water } \\
\text { reservoirs and demand for water irrigation }\end{array}$ \\
\hline & & $\begin{array}{l}\text { Increased risk of habitat loss (mangroves), } \\
\text { salt intrusion }\end{array}$ \\
\hline \multirow{7}{*}{$\begin{array}{l}\text { Human settlements and } \\
\text { infrastructure }\end{array}$} & Tropical cyclones & Housing and infrastructure damage \\
\hline & Heavy precipitation & Housing and infrastructure damage \\
\hline & & $\begin{array}{l}\text { Need for new or upgraded flood control and } \\
\text { erosion control structures }\end{array}$ \\
\hline & & Landslides, road washouts and flooding \\
\hline & & $\begin{array}{l}\text { Increased demands on storm water } \\
\text { management systems and sewer overflows }\end{array}$ \\
\hline & Sea level rise & Reduced effectiveness of sea walls \\
\hline & & Housing and infrastructure damage \\
\hline \multirow[t]{2}{*}{$\begin{array}{l}\text { Health, food and waste } \\
\text { management }\end{array}$} & Heavy precipitation & $\begin{array}{l}\text { Increase in vector-borne diseases (malaria, } \\
\text { cholera, etc.) }\end{array}$ \\
\hline & & $\begin{array}{l}\text { Need for a new waste collection, management } \\
\text { and treatment system }\end{array}$ \\
\hline
\end{tabular}

Table 2. Population change from 1997 to 2007 in seven districts in Maputo.

\begin{tabular}{lccc}
\hline Municipal districts & 1997 Census population & 2007 Census population & Difference 1997:2007 \\
\hline Kaphumu (Nr. 1) & 154,284 & 108,096 & $-46,188$ \\
KaChamanculu (Nr. 2) & 162,750 & 154,272 & $-8,478$ \\
KaMaxaqueni (Nr. 3) & 210,551 & 223,628 & 13,077 \\
KaMavota (Nr. 4) & 228,244 & 293,270 & 65,026 \\
KaMubukwani (Nr. 5) & 211,008 & 290,775 & 79,767 \\
KaTembe (Nr. 6) & 15,853 & 19,371 & 3,518 \\
KaNhaca (Nr. 7) & 4,672 & 5,216 & 544 \\
Total & 987,362 & $1,094,628$ & 107,266 \\
\hline
\end{tabular}

Source: INE (2012). 
Table 3. Multi-dimensional poverty index indicators for Mozambique.

\begin{tabular}{|c|c|c|c|c|c|c|c|}
\hline \multirow[b]{2}{*}{$\begin{array}{l}\text { Sub-national } \\
\text { region }\end{array}$} & \multicolumn{3}{|c|}{ Multidimensional poverty of the region } & \multirow[b]{2}{*}{$\begin{array}{c}\text { Population } \\
\text { vulnerable to } \\
\text { poverty } \\
\text { (experiencing } \\
\text { intensity } \\
\text { between } 20 \\
\text { and } 32.9 \%) \\
(\% \\
\text { population) }\end{array}$} & \multirow[b]{2}{*}{$\begin{array}{l}\text { Population in } \\
\text { severe } \\
\text { poverty } \\
\text { (experiencing } \\
\text { intensity } \\
\text { higher than } \\
50 \% \text { ) (\% } \\
\text { population) }\end{array}$} & \multirow[b]{2}{*}{$\begin{array}{c} \\
\text { Total } \\
\text { population } \\
\text { in } 2009 \\
\text { (thousands) }\end{array}$} & \multirow[b]{2}{*}{$\begin{array}{l}\text { Number of } \\
\text { MPI poor } \\
\text { people } \\
\text { (thousands) }\end{array}$} \\
\hline & $\begin{array}{l}\text { Multidimensional } \\
\text { Poverty Index } \\
\text { (MPI }=H^{*} A \text { ) } \\
\text { (range } 0-1 \text { ) }\end{array}$ & $\begin{array}{l}\text { Headcount ratio: } \\
\text { population in } \\
\text { multidimensional } \\
\text { poverty }(H) \\
(\% \text { population })\end{array}$ & $\begin{array}{c}\text { Intensity of } \\
\text { deprivation } \\
\text { among the } \\
\text { poor }(A) \\
\text { (average \% } \\
\text { of weighted } \\
\text { deprivations) }\end{array}$ & & & & \\
\hline Mozambique & 0.512 & 79.3 & 64.6 & 9.5 & 60.7 & 22859 & 18127 \\
\hline $\begin{array}{l}\text { Maputo } \\
\text { Provincia }\end{array}$ & 0.295 & 52.2 & 56.5 & 11.4 & 34.4 & 1339 & 699 \\
\hline $\begin{array}{l}\text { Maputo } \\
\text { Cidade }\end{array}$ & 0.194 & 44.3 & 43.9 & 7.9 & 10.2 & 1116 & 494 \\
\hline
\end{tabular}

Source: Adapted from Alkire et al. (2011a) and Alkire et al. (2011b).

three dimensions with 10 different weighted indicators for health, education and living standards (Alkire et al. 2011a). ${ }^{1}$ The MPI provides a headcount ratio of the percentage of people affected by poverty $(H)$ and the average intensity of the index in different dimensions $(A)$. The indicator distinguishes between poverty (deprived in at least $33 \%$ of the indicators) and severe poverty (deprived in at least $60 \%$ of the indicators). Table 3 provides an overview of the MPI in Mozambique and Maputo. The indicators suggest that poverty rates are considerably lower in Maputo city than in the rest of the country. In Mozambique, the percentage of population affected by poverty is $79.4 \%$ (60.7\% in severe poverty). Moreover, the intensity of poverty is also high. In Maputo city the percentage of people in poverty is reduced to $44.3 \%$, which lower deprivation intensity, and only $10.2 \%$ experiencing severe poverty, although it is worthy considering that indexes of deprivation increase considerably in Maputo province and that an additional $7.9 \%$ in the city are at risk of poverty. The decomposition of the data by indicators shows that access to services such as energy, cooking fuel and sanitation are the indicators in which more than $60 \%$ of the population is deprived (Alkire et al. 2011b). Access to services and infrastructure constitutes one of the main aspects of urban deprivation in Maputo.

Government authorities and experts link vulnerability to floods to a proliferation of unplanned human settlements during the last three decades, which has gradually expanded to topographically depressed and marshy areas characterised as having high flood risk. A resident of the Mafalala neighbourhood, an old and declined residential area in Maputo, explained in an interview with ActionAid: "Our houses are built in low areas. We have no shelter when the flood starts. The house owners do not help us to drain out water from our homes. People use buckets to remove water themselves. Once water has gone, the real disaster has just begun. That is: diseases" (ActionAid 2006, p. 1). The government of Mozambique approved a National Slum Upgrading Strategy in 2010, which defined "slum" as an urban area, which showed one or more of the following parameters:

- general lack of urban infrastructure and services, in particular water and sanitation;

- ambiguous and insecure land tenure, compounded with the weak perception of such

- situation as a problem;

- high density of dwellers resulting in insufficient living space per person;

- inadequate environmental conditions;

- low or very low quality of construction, with structural deficiencies and reduced

- durability of the dwelling; 
- lack of an urban culture and weak citizenship feeling and

- high levels of criminality and marginality.

All these factors impinge in the adaptive capacity of citizens and communities. Some of the factors are environmental, in the sense that they derive from the material aspects of the human settlements (e.g. inadequate environmental conditions, low quality of construction, high density and lack of living space). Climate change hazards are likely to exacerbate pollution and affect living space and built structures. While people living in informal settlements may be accustomed to get across in spite of the deficient provision of services this means that climate hazards will add to an already precarious situation. Insecurities or ambiguities in land tenure are more of a problem for government institutions which aim at establishing formal strategies for land planning and management. These strategies may clash with informal strategies to access land and resources. Finally, informality is often associated with lack of citizenship and high levels of criminality and marginality. This, however, should be understood within the context of exclusion and deprivation in which some informal settlement dwellers live. First of all, lack of resources may make impossible for citizens to show commitment to urban culture. Second, criminality and marginality should be understood by considering that those bairros also host the majority of the workforce, in bigger densities than the concrete city does. In that sense, the social observations of the strategy should not be understood as a comment on the actual lives of the people in these settlements, but rather, as the perceived representations by officials of informal settlement dwellers, which do not necessarily recognise the multiple forms of agency within human settlements.

The example shows how interwoven socio-ecological factors intervene in the production and intensification of climate change vulnerabilities. These include the climate hazards and the capacity of citizens to draw resources and maintain their livelihoods as vulnerability studies frequently emphasise. However, vulnerabilities also depend on additional factors which result from human-ecological interactions, including the use of resources and access to services through infrastructures; the availability of space both to support daily lives and livelihoods; the access to food resources; existing building practices and environmental resources. The following section turns to analyse the governance opportunities to address existing vulnerabilities in Maputo.

\section{Governance opportunities to address existing vulnerabilities in Maputo}

In addition to the in-depth vulnerability assessment summarised in the previous section, UN-Habitat investigated the potential for intervention in climate change governance in Maputo. First, the programme investigated the governance context with an overview of the main stakeholders that could participate in the development of the CCCI program in Maputo (Table 4). The biggest role corresponds to the Ministry of Coordination of Environmental Affairs (MICOA), the National Institute for Disaster Management (INGC) and Maputo Municipal Council (MMC). In order to evaluate how they would operate as counterpart organisation, UN-Habitat carried out a Strength-Weakness-OpportunitiesThreats analysis, which is presented in Table 5. The table emphasises the differential capacity of each organisation and its potential to reach different actors. MICOA acts as the UNFCCC focal point and has a solid framework to develop national-wide climate change plans. However, the environmental coordination mandate is too broad, and often, there is poor enforcement. INGC is a pro-active, multi-disciplinary organisation, with strong community involvement, but lacks resources and it has seldom intervened at the urban level. MMC has gained weight through the process of decentralisation and has 
Table 4. Key institutions and actors identified by UN-Habitat to develop a climate change strategy for Maputo.

Key institutions and actors

Maputo Municipal Government

Ministry of State Administration (Ministério da Administração Estatal - MAE)

National Disaster Management Institute (INGC)

Ministry for Coordination of Environmental Affairs (Ministério para a Coordenação da Acção Ambiental - MICOA)

Ministry of Public Works and Housing (Ministério das Obras Públicas e Habitação - MOPH)

Ministry of Science and Technology (Ministério da Ciência e Tecnologias - MCT)

National Association of Municipalities of Mozambique (Associação Nacional dos Municipios Moçambicanos - ANAMM)

The academic sector

Civil society and private sectors
Key responsibilities in relation to climate change

MMC is the main focal point at city level, with key responsibilities of (i) developing climate change adaptation urban plans; (ii) coordinating the planning and execution of pilot interventions; (iii) benefiting from training and capacity building programmes and (iv) serving as intermediary to access the final beneficiaries; and the vulnerable population at the neighbourhood level, or slum dwellers, also organised in community-based organisations or community associations

Works directly with the 43 established municipal authorities in Mozambique including MMC, through its National Directorate for Autarkic Development (Direcção Nacional de Desenvolvimento Autarquico - DNDA). It also leads the The inter-ministerial committee for municipal development (Grupo Inter-Ministerial para o Desenviolvimento Autarquico - GIDA)

Set up in 1999, the institute has the mandate to ensure a permanent state of readiness and an effective capacity to respond to natural disasters. It has a Technical Council, including experts from various state bodies, and a Natural Disaster Management Coordinating Council, which is chaired by the Prime Minister, includes other relevant ministers and reports regularly to the Council of Ministers

MICOA, in particular through its National Directorate for Territorial Planning (Direcção Nacional de Planeamento e Ordenamento Territorial - DINAPOT), is a coordinating governmental institution, responsible for regulating urban planning activities at the national level

MOPH is responsible for the implementation of the recently approved Housing policy through its National Directorate of Housing and Urbanisation (Direcção Nacional de Habitação e Urbanismo - DNHU)

Responsible for testing innovative and sustainable solutions/technologies for mitigating/adapting to climate change-related impacts

Has an important role in coordinating action across municipalities and enabling action through advocacy and demonstration

The Eduardo Mondlane University (Universidade Eduardo Mondlane - UEM) in Maputo is involved in the development and testing of climate change adaptation/mitigation tools and methods, especially through the Faculties of Architecture and Physical Planning, Engineering and Sciences

Although these are essential partners, UN-Habitat is yet to identify key actors who can help to move the strategy forward, other than Economic Forum for Environment (Fórum Económico para o Meio Ambiente - FEMA) 
Table 5. Key institutions SWOT.

\begin{tabular}{|c|c|c|}
\hline Stakeholder & Strengths & Weaknesses \\
\hline MICOA & $\begin{array}{l}\text { - Government coordinating institution } \\
\text { concerning CC and environmental } \\
\text { issues } \\
\text { - Focal point institution for implementing } \\
\text { of the UNFCCC }\end{array}$ & $\begin{array}{l}\text { - Lack of qualified human resources, } \\
\text { policy and/or strategy for dealing with } \\
\text { CC-related impacts in urban areas } \\
\text { - Poor enforcement/revision capacity of } \\
\text { existing policies and strategies }\end{array}$ \\
\hline INGC & $\begin{array}{l}\text { - Pro-active and experienced management } \\
\text { team } \\
\text { - Strong community involvement when } \\
\text { implementing plans, strategies and } \\
\text { interventions }\end{array}$ & $\begin{array}{l}\text { - Few interventions at urban level } \\
\text { - Lack of qualified human resources for } \\
\text { dealing with CC-related impacts in } \\
\text { urban areas }\end{array}$ \\
\hline MMC & $\begin{array}{l}\text { - Decentralised organisational structure } \\
\text { set up through municipal elections } \\
\text { - New transparency governance policy } \\
\text { - Improved managerial/technical capacity } \\
\text { for dealing with urban management/ } \\
\text { planning issues }\end{array}$ & $\begin{array}{l}\text { - No managerial/technical unit dealing } \\
\text { with CC-related impacts at city level } \\
\text { - Lack of methods and tools to address } \\
\text { CC-related impacts at the city level }\end{array}$ \\
\hline MICOA & $\begin{array}{l}\text { - Solid legal, policy and strategic } \\
\text { framework for dealing with CC (NAPA, } \\
\text { Environmental Strategy for Sustainable } \\
\text { Development, etc.) } \\
\text { - Good partnerships and integration of } \\
\text { various on-going CC projects } \\
\text { - Good financing and technical } \\
\text { partnerships }\end{array}$ & $\begin{array}{l}\text { - Environmental coordination mandate is } \\
\text { too broad, ending up in a weak } \\
\text { attention on its policies from the other } \\
\text { sectors }\end{array}$ \\
\hline INGC & $\begin{array}{l}\text { - Wide, innovative and multi-disciplinary } \\
\text { disaster risk reduction approach, with a } \\
\text { decentralised vision } \\
\text { - Excellent financing partnership with the } \\
\text { World Bank, producing positive capital } \\
\text { investments on urban infrastructure }\end{array}$ & $\begin{array}{l}\text { - Budget constraints } \\
\text { - Limited human resources compared to } \\
\text { the needs }\end{array}$ \\
\hline $\mathrm{MMC}$ & $\begin{array}{l}\text { - Increased sense of responsibility of } \\
\text { service delivery for the urban poor } \\
\text { - Openness for bringing the CC urban } \\
\text { dimension to the discussion table and } \\
\text { for drafting a first CC Adaptation and } \\
\text { Mitigation Master Urban Plan of } \\
\text { Maputo city }\end{array}$ & $\begin{array}{l}\text { - Budget constraints } \\
\text { - Limited human resources compared to } \\
\text { the needs }\end{array}$ \\
\hline
\end{tabular}

Source: UN-Habitat, CCCI.

taken responsibilities for delivering services to the urban poor, but still lacks capacity and resources to deliver such benefits at the city-wide level.

The implication of this analysis is that the MMC is a key actor to consider in delivering effective action for the urban poor in Maputo in the context of climate change. Mozambique has a positive decentralisation story to share. A multi-organisational report on municipal governance in Mozambique (WB 2009) found that since decentralisation started in 1997 municipal governments have had an important role in reducing poverty and stimulating investment. Some of the initiatives that have been highlighted as successes have been the simplification of municipal financial systems, including participatory budgeting exercises, and the establishment of public-private partnerships for service delivery in several cities including Maputo. Although it may be too early to address the question of whether decentralisation has really delivered improvements in the quality of life of Maputo citizens, 
as they perceive their own needs, the example of Mozambique highlights the potential for decentralisation to improve local governance of services and development programmes. In Mozambique, municipalities play a key role in land tenure and land security, providing food security and access to services, investment and employment relations all of which can contribute directly to the capacity of different actors in Maputo to adapt to climate change. Their role has been strengthened through advocacy and coordination activities facilitated by the Association of Municipalities (ANAMM).

UN-Habitat reviewed the key governing instruments and policies for urban development in Maputo, through which climate change action could be channelled (Table 6). The two main instruments at the city level are the Urban Master Plan of Maputo Municipality (Plano de Estrutura Urbana do Municipio de Maputo: PEUMM) and the Maputo Municipal Development Program (Programa de Desenvolvimento Municipal de Maputo: PRO-MAPUTO). PEUMM was approved in 2008 and addresses the main aspects to define a spatial vision and strategic planning priorities of the city, as well as providing guidelines for public investment. In addressing climate change, PEUMM identifies sensitive areas of Maputo city which are vulnerable to extreme events related to climate change and provides guidelines for future urban development interventions. Some strategic activities include among others: slum upgrading; land re-qualification for installing social/ public services and equipment; land provision for urban expansion; promotion of urban diversification of activities and functions; measures to avoid both the formation of periurban slum and the spatial segregation of poor communities; and reduction of social differentiation by providing infrastructure, services and equipment in slum areas, all of which recognise the social and material linkages of development under climate change.

PRO-MAPUTO, under implementation since April 2007, is MMC's main operational programme aiming to increase the level of investment in infrastructure and service delivery and improve priority municipal services such as land use management, solid waste, sustainable management, water supply and sanitation, roads, among others. PRO-MAPUTO does not address climate change explicitly but provides guidelines for interventions that will reduce vulnerabilities. According to the plan, a significant part of these investments will take place in the city's poorest areas. The Urban Planning and Environment Component of PRO-MAPUTO comprises activities for improving the quality of urban environment, as well as implementing prevention measures and environment risk management. Both PEUMM and PRO-MAPUTO need to be understood within the context of other policies and strategies existing at the national and local level and sectoral policies for waste, water, energy and planning (Table 6). Despite challenges in implementation and delivery, both PEUMM and PRO-MAPUTO demonstrate the leadership potential existing within the local government to address climate change-related vulnerabilities.

This realisation has led to an increasing recognition within the country of the important role that local governments can play in addressing climate change. For example, the National Institute for Management of Calamities (INGC) provides resources and technical assistance to relevant public sector bodies in order to prevent, mitigate and respond to humanitarian emergencies and natural disasters (Table 4). However, there have been several cases of disasters in which municipal authorities were not only involved but also assumed leadership roles both in the coordination of immediate relief actions and the provision of assistance for reconstruction (WB 2009). After these experiences, the role of local governments in both mobilising communities and providing relief services has been increasingly recognised by INGC.

One of the significant absences in UN-Habitat's stakeholder list is business and civil society organisations. While the report recognises that alliances with such organisations 
Table 6. Main policies in Mozambique relevant to CCCI.

Key national policies, strategies and plans related with climate change and urban development

\begin{tabular}{|c|c|c|c|c|}
\hline Policy/strategy title & Main objective(s) and purpose & $\begin{array}{l}\text { Strategic activities or main } \\
\text { contents }\end{array}$ & $\begin{array}{l}\text { Urban and climate change } \\
\text { issues }\end{array}$ & $\begin{array}{l}\text { Relevance to the SUD-Net } \\
\text { CCCI }\end{array}$ \\
\hline $\begin{array}{l}\text { Agenda } 2025 \text { (Adopted in Nov. } \\
\text { 2003) }\end{array}$ & $\begin{array}{l}\text { - To improve socio-economic } \\
\text { situation of Mozambique by } \\
2025\end{array}$ & $\begin{array}{l}\text { - Social capital } \\
\text { - Economic development } \\
\text { - Governance }\end{array}$ & $\begin{array}{l}\text { - It does not provide attention } \\
\text { to CC impacts in urban } \\
\text { areas } \\
\text { - However it places human } \\
\text { settlements and sustainable } \\
\text { urban development as one } \\
\text { of the main priorities }\end{array}$ & $\begin{array}{l}\text { - The CCCI appears to fit well } \\
\text { in the Agenda's strategic } \\
\text { programme, and constitutes } \\
\text { an opportunity to fulfil } \\
\text { existing gaps concerning CC }\end{array}$ \\
\hline $\begin{array}{l}\text { Absolute Poverty Reduction } \\
\text { Action Plan 2006-2009 } \\
\text { Plano de Acção para a } \\
\text { Redução da Pobreza } \\
\text { Absoluta II (PARPA II) } \\
\text { (approved in 2006) }\end{array}$ & $\begin{array}{l}\text { This plan influences all } \\
\text { donors support to } \\
\text { Mozambique during four } \\
\text { years }\end{array}$ & $\begin{array}{l}\text { - Governance } \\
\text { - Human capital } \\
\text { - Economic Development }\end{array}$ & $\begin{array}{l}\text { Natural disasters and urban } \\
\text { areas are treated as cross- } \\
\text { cutting issues; however, } \\
\text { urban development does not } \\
\text { constitute a priority }\end{array}$ & $\begin{array}{l}\text { - Poverty, which can be seen } \\
\text { also as a consequence of CC } \\
\text { impacts in urban areas, is } \\
\text { addressed from a general } \\
\text { perspectives } \\
\text { - The CCCI in Maputo can play } \\
\text { a strategic role in } \\
\text { mainstreaming both urban } \\
\text { development and CC issues } \\
\text { into such crucial planning } \\
\text { instrument }\end{array}$ \\
\hline $\begin{array}{l}\text { National Adaptation Plan of } \\
\text { Action to Climate Change } \\
\text { (NAPA) Programa de Acção } \\
\text { Nacional para a Adaptação } \\
\text { às Mudanças Climáticas } \\
\text { (Approved in 2007) }\end{array}$ & $\begin{array}{l}\text { - To identify the country's } \\
\text { urgent needs through a } \\
\text { participative assessment } \\
\text { process } \\
\text { - The implementation of this } \\
\text { plan should increase the } \\
\text { national capacity to deal } \\
\text { with climate change impacts }\end{array}$ & $\begin{array}{l}\text { - Strengthening of the } \\
\text { warning system for natural } \\
\text { disaster prevention } \\
\text { - Capacity building and } \\
\text { awareness raising of } \\
\text { agriculture producers to } \\
\text { deal with climate change } \\
\text { effects } \\
\text { - Reducing climate change } \\
\text { impacts in the coastal areas }\end{array}$ & $\begin{array}{l}\text { - It does not provide attention } \\
\text { to } \mathrm{CC} \text { impacts in urban } \\
\text { areas }\end{array}$ & $\begin{array}{l}\text { - The CCCI in Maputo can be } \\
\text { instrumental in stressing on } \\
\text { the high vulnerability of } \\
\text { coastal cities to CC effects } \\
\text { - More, in general, the CCCI } \\
\text { can raise awareness on } \\
\text { sustainable urban } \\
\text { development in general, } \\
\text { especially considering the } \\
\text { increasing negative impacts } \\
\text { of CC in the future }\end{array}$ \\
\hline
\end{tabular}


Table 6. Continued.

Key national policies, strategies and plans related with climate change and urban development

\begin{tabular}{|c|c|c|c|c|}
\hline Policy/strategy title & Main objective(s) and purpose & $\begin{array}{c}\text { Strategic activities or main } \\
\text { contents }\end{array}$ & $\begin{array}{l}\text { Urban and climate change } \\
\text { issues }\end{array}$ & $\begin{array}{l}\text { Relevance to the SUD-Net } \\
\text { CCCI }\end{array}$ \\
\hline
\end{tabular}

- Improving water resources

management

Environmental Strategy for Sustainable Development of Mozambique Estratégia Ambiental para o Desenvolvimento Sustentável de Moçambique (Approved in 2007)
Master Plan for Prevention and Mitigation of Natural

Disasters Plano Director para Prevenção e Mitigação of a common vision for sustainable

environmental management in Mozambique, which will contribute to poverty principles of the Agenda 21 and NEPAD

- Establishment of stakeholders guidelines for implementing development programs, including NGOs, private sector, scientific and academic community, civil society and international partners eradication based on

- To complement the PARPA II and to fill in strategic gaps in the different governmental sectors related to risk management,
Capacity building for the implementation of strategies including the establishment of goals at national and local level to achieve integrated management and protection of natural resources and ecosystems

- Creation of institutions with technical capacity for urban planning, development of infrastructures, waste management, and water and sanitation services

- Strengthening the country's capacity to measure, reduce and evaluate environmental pollution including impact on health and climate change issues by providing technical and financial support

- Keeping the population growth within the limit of socio-economic goals and sustainable development objectives

- It refers to urban

- It includes a slum upgrading

- Climate change issues are

- Achieving a balanced use of $\bullet$ Disaster risk mapping for water resources, in particular by storing the excess produced by environment but not in particular to climate change impacts in cities strategy in its urban environment chapter, which was supported by UN-

HABITAT in 2004/2005 discussed but mainly from an atmospheric pollution perspective, by specifying a range of actions to be implemented in order to fulfil the government

UNFCCC compromises and terms

- This strategy can be used as general framework for designing a municipal $\mathrm{CC}$ adaptation action plan for Maputo city

- The CCCI is an opportunity to build on the slum upgrading strategy supported by UNHABITAT in the recent past, which is part of the urban environment chapter planning \& monitoring purposes
- This Master Plan introduces several innovative concepts, such as maximising the use of local techniques and 
das Calamidades Naturais

(Approved in 2006) vulnerability reduction, prevention and mitigation of natural disasters

- To recognise effective disaster management as a key component of both poverty reduction and sustainable development
National Water Policy Política Nacional de Águas (Adopted in 2007)
- To guarantee sufficient wate resources in quantity and quality for the present and future generations

- To focus on poverty reduction, peace promotion, well being and good flooding for using during

the drought periods

- Ensuring a food and nutritional balance through application of improved cropping techniques, introduction of resistant species, seed provision and development of non agriculture activities with economic value

- Reinforce disaster emergency management by developing conditions for a prompt response, decentralised decisionmaking and early recovery capacity

- To improve access to water for human consumption in accordance with the MDGs

- It stresses the need for improving drainage systems in urban areas, thus minimising the impacts provoked by flooding in infrastructure

- To improve access to decent - It promotes investment for sanitation for preventing facilitating access to drinking water, which is

- Introduction of agricultura conservation techniques, and strengthening of local

- Application of local land use planning methodologies

self-esteem and confidence

in its capacities

water-borne disease

capacities while planning and identifying coping solutions

- In general, it does not focus on urban-related aspects and contemplates the impacts of $\mathrm{CC}$ in a partial manner
- The CCCI in Maputo can constitute a show case by actually implementing some of the innovative components presented by the Master Plan and, in the mean time, help mainstreaming urban and $\mathrm{CC}$ aspects into Government DRR policies

- This will be a fundamental policy instrument to use while identifying appropriate water and sanitation adaptation/coping strategies during the $\mathrm{CCCI}$ in Maputo 
Table 6. Continued.

Key national policies, strategies and plans related with climate change and urban development

\begin{tabular}{|c|c|c|c|c|}
\hline Policy/strategy title & Main objective(s) and purpose & $\begin{array}{l}\text { Strategic activities or main } \\
\text { contents }\end{array}$ & $\begin{array}{l}\text { Urban and climate change } \\
\text { issues }\end{array}$ & $\begin{array}{l}\text { Relevance to the SUD-Net } \\
\text { CCCI }\end{array}$ \\
\hline & $\begin{array}{l}\text { practices, and to minimise } \\
\text { the negative impacts of } \\
\text { floods and drought }\end{array}$ & $\begin{array}{l}\text { - To promote the efficient use } \\
\text { of water supply } \\
\text { infrastructure } \\
\text { - To contribute to floods and } \\
\text { drought vulnerability } \\
\text { reduction } \\
\text { - To promote peace and } \\
\text { regional integration }\end{array}$ & $\begin{array}{l}\text { currently producing positive } \\
\text { results in city centres, but } \\
\text { not yet in peri-urban slum } \\
\text { areas }\end{array}$ & \\
\hline
\end{tabular}

National Water Resources

Management Strategy

Estratégia Nacional de

Gestão de Recursos Hídricos

(Approved in 2007)
- To develop effective and integrated management of water resources for contributing to sustainable socio-economic development
National Energy Strategy

Estratégia Nacional de

Energia (Approved in 2000)
- It aims at increasing the number of users having access to energy sources, especially by promoting efficient use and environmental protection regional integration

- To build human capacity for - It explains how floods water resource management should be managed, without differentiating urban and rural areas

- To develop infrastructure for - CC -related issues are water supply \& sanitation services

- To develop a framework for integrated water management

- To support policies for ensuring a sustainable and diversified use of water resources

- To ensure low cost energy supply

- To increase the energy availability for the domestic sector

- To promote reforestation in order to increase the availability of biomass fuel

- To strengthen the capacity of stakeholders involved in energy supply for generally not mainstreamed in the strategy
- It does not show how currently applied energy supply strategies have climate change implications and what mitigation strategies can be proposed for minimising related impacts in urban areas

- The CCCI can represent an added-value for including an analysis of climate change impacts in water resources management for urban areas

- The CCCI will be important for proposing adequate measures for mitigating $\mathrm{CC}$ related impacts by applying energy saving and reforestation activities in urban and peri-urban areas 
Territorial Planning Law and Policy Política e Lei de

Ordenamento Territorial (Approved in 2007)
- These instruments create a legal and policy framework for territorial planning and sustainable urban

development at the national level improving their

performance and efficiency

- To promote development and use of renewable energy

(solar, wind and bio-fuels)

- To ensure people's right to access land and its resources

- To implement slum upgrading

- To value socio-economic and cultural activities

- To protect the ecologica quality of soils and water resources, and develop a legal framework for their optimised used and access
- These legal/policy tools do not specifically refer to the impacts of climate change
- Relevant as a reference to urban issues

Strategic plans and programmes at Maputo's municipal level which are relevant to the CCCI

Plan/programme title

Maputo Municipal

Development Programme

(PRO-Maputo) Programa de

Desenvolvimento Municipal

de Maputo (Approved in 2006)
Main objective(s) and purpose Strategic activities or main contents

- To improve the life quality of - Governance: to ensure citizens through a threephased development strategy framework for the period 2007-2016

- Phase 1: to strengthen the MMC institutional and financial capacity for supporting the achievement of long-term service strategic, efficient and participative municipal management

- Municipal finances: to improve the revenue system and promote efficient expenditure

- Planning and improvement
Climate change issues

- Climate change is not a specifically addressed by the programme

- However some physical interventions that are carried out to improve road drainage and coastline protection infrastructure
Relevance to the SUD-Net CCCI

- This is probably the most important on-going programme under implementation by the $\mathrm{MMC}$ with which the CCCI needs imperatively to coordinate, as it represents a clear source for follow-up investments after the pilot phase 
Table 6. Continued.

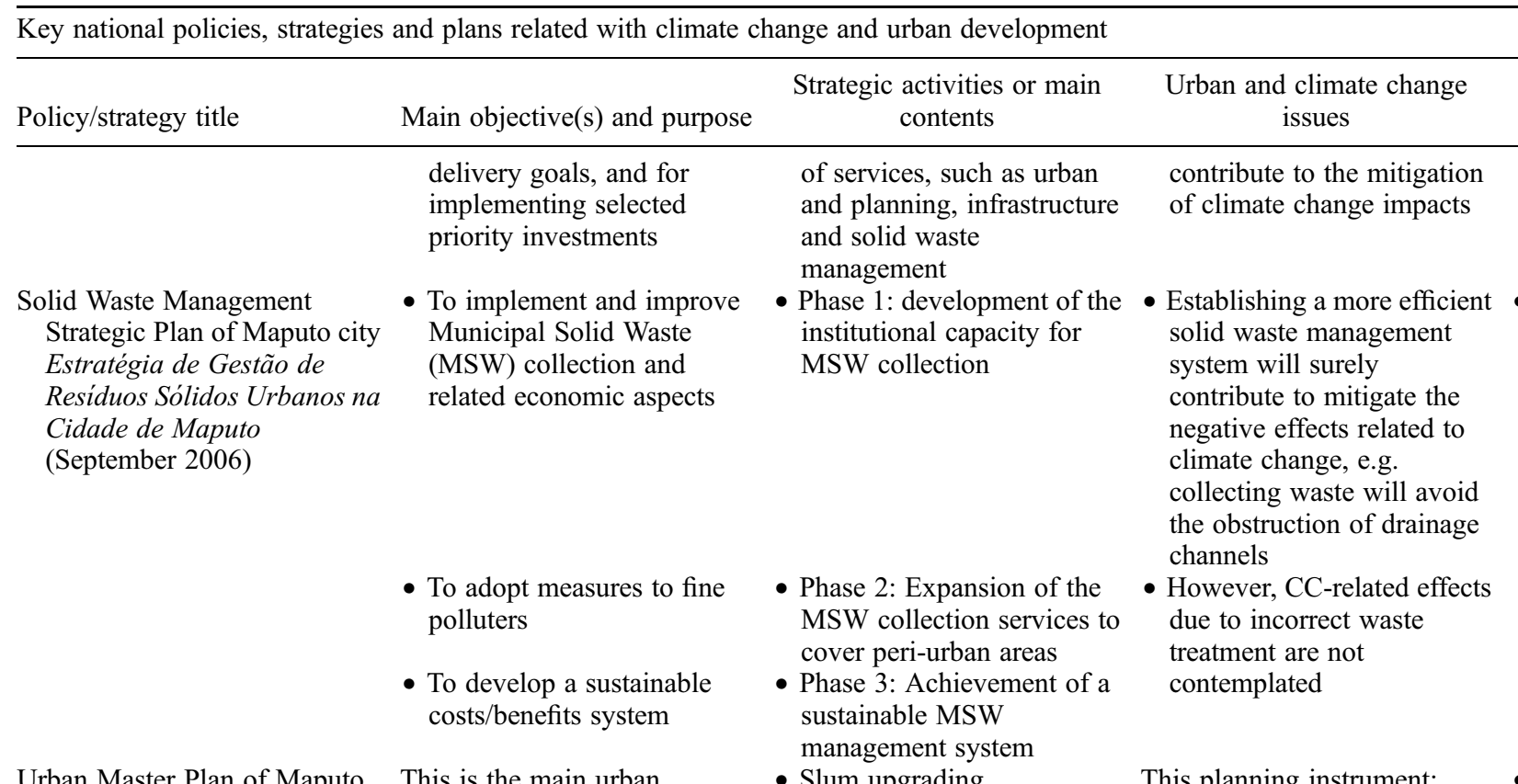

rban Master Plan of Maputo Municipality Plano de Estrutura Urbana do Municipio de Maputo (PEUMM) (approved in 2008)
This is the main urban planning instrument of Maputo city, which:

- defines the spatial vision and strategic planning priorities of the city

- identifies priority areas for public investment

- establishes the municipal principles for addressing issues related to urban planning

\section{- Slum upgrading}

- Land requalification for installing the social/public services and equipments

- Land provision for urban expansion

- Reserve of green areas for guaranteeing ecological and environmental quality

Relevance to the SUD-Net CCCI

- The CCCI will allow providing the MMC a more comprehensive strategy of solid waste management which contributes to the mitigation of $\mathrm{CC}$ effects

This planning instrument:

- identifies sensitive areas of Maputo city which are vulnerable to extreme events related with climate change

- provides guidelines for future urban development interventions also related with $\mathrm{CC}$ impacts
- This plan will be a crucial reference tool for implementing the $\mathrm{CCCI}$ in Maputo

- Through this initiative, the $\mathrm{CC}$ aspects of the plan will be strengthened 
- provides clear guidelines for private investments and/or initiatives

- establishes a simple data collection system which can be permanently updated

Sustainable Consumption and Production (SCP) for Maputo and Matola Cities Consumo e Produção Sustentável para as Cidades de Maputo e Matola (2007) up of the 10-year

Framework Programme on

Sustainable Consumption

and Production in Africa,

which identifies key
- Establishment of minimum conditions for ensuring proper transit flow and mobility

- Promotion of social housing construction

- Promotion of urban agriculture development

- Promotion of urban

diversification of activities and functions, avoiding the formation of peri-urban slum and spatial segregation of poor communities

- Reduction of social differentiation by providing infrastructure, services and equipments in slum areas

This SCP initiative is a follow - Water and sanitation

priorities concerning the

thematic areas of energy,

water, urban development,

and industrial development sustainability

- Urban development and infrastructure
- It does not address specifically potential climate change impacts in urban areas
- Some of the assessment methodologies used in the SCP programme could be applied within the framework of the CCCI in Maputo

Source: UN-Habitat, CCCI 
are crucial, both to deliver cross-sectoral action and to reach the urban poor, the analysis does not go beyond different levels of government. Civil society in Mozambique is relatively fragmented. The World Bank (2009) report on decentralisation explains that multiple forms of grassroots mobilisation were started by FRELIMO as the foundation for popular socialism, which resulted in current forms of social organisation alongside bairros (neighbourhoods) and quarteirao (blocks). Other FRELIMO-linked mass organisations are the Mozambican Women's Organization and the Mozambican Youth Organization. These relatively formal institutions coexist with a traditional system of organisation that emerges from social structures predating colonisation. The reliance of the country on international aid has led to the proliferation of multiple civil society organisations acting as interest-led NGOs, whether they are local subsidiaries of international organisations or local associations. The private sector is mixed, but given the structure of the economy, attention should be paid to small businesses, many of them operating in a relatively informal manner and often organised alongside customary structures for trade organisation. All these groups have a role to play in reducing vulnerabilities, whether this is by enabling forms of social regulation or by creating livelihood opportunities and drawing resources to increase resilience. However, such role is still not clearly understood.

An example of the case of primary waste collection in Maputo city can demonstrate the importance of multiple organisations and actors in implementing effective environmental action and the supporting role that municipal authorities can play. Peri-urban bairros have narrow and unpaved street which could not be reached with conventional systems for waste collection. In these areas, inhabitants are forced to bury, burn or dispose of waste in inappropriate places. According to the World Bank (2009), a door-to-door system for waste collection has been implemented in two of these neighbourhoods called Maxaquene A and Urbanizaçao. The main mode of transport is tchovas, small carts carried by individual operators, which bring the waste to secondary collection points with stationary containers where the waste can be collected by trucks. The Municipal Service Directorate of Health (DSMSS) is in charge of collecting the waste from the stationary containers, while the tchovas are operated by small-sized companies within the neighbourhood, generating work and income for local inhabitants. NGOs may also be involved in managing the composting or providing initial capital to buy better quality tchovas.

This example suggests that there is a great potential for the involvement of multiple actors other than the government in bringing about effective climate change action in Maputo. Moreover, the example shows that some local actors may operate in specific ways suited to the material and social context of the city. In this case, small local operators are able to first, contact citizens in a door-to-door basis and second, use tchovas to deal with the difficulties pose by the existing layouts in this neighbourhood. The CCCI institutional analysis in Maputo suggests that there is potential for existing institutions to work in partnership with other non-governmental actors or to enable their work, but it also reveals a clear gap in understanding who these actors are, how they operate and how they could be better supported to advance progressive action for climate change in Maputo.

\section{Conclusion}

African cities are highly diverse, not only in terms of their history, social configuration, institutional and political systems and economies but also in their exposure to climate change risks. In that sense, the case of Maputo (like other CCCI examples) should not be regarded as a case that provides the basis for best practice examples to be generalised across African cities. Rather, it should be approached as bringing to light the difficulties 
to envisage progressive experimental action for climate change in African cities without understanding the context of each city, in terms of the drivers of change, the capacity for action of different actors and the social, spatial and environmental patterns that emerge from the interaction between drivers and actors' actions. Lessons from Maputo could inform other urban contexts, from New Orleans to Bangkok, insofar as the actors involved recognise similar socio-ecological patterns as shaping their experience of the city.

This case shows two aspects that need to be considered in climate change governance, particularly when rhetorical arguments addressing climate change vulnerabilities are to be put in practice. First, the case highlights the need to approach the city as a socio-ecological and socio-technical entity, characterised by the production of socio-natures. These socionatures have a key role in producing urban inequality - for example, inequalities in climate change vulnerability - and highlight that spatial and environmental effects are often associated with social ones and vice versa. Now it is broadly accepted that local vulnerabilities to climate change have to be understood in the context of social and economic interactions. The capacity of actors to respond to events, to access resources and to influence decisions will shape climate change vulnerabilities alongside environmental impacts. However, when taking planning decisions, the biophysical realm is often approached as if it were separated from the social and institutional forces which shape it. In these cases, risk mitigation actions may not only be less effective, but also they may have unintended consequences which may reverse their benefits.

Second, the case suggests that effective governance strategies for climate change require recognising multiple actors intervening in urban life and urban development. Government institutions alone, whether this is at the local or national levels, cannot provide a full response to climate change in the city. Existing experiences such as that of Maputo show that the involvement of small scale private actors and communities is likely to generate important opportunities. While there is potential for different actors to work in isolation, partnership emerges as a key strategy to transcend institutional and material barriers to climate change action through numerous forms of institutional experimentation. Action for climate change will require recognising existing interactions and build on positive experiences, rather than portraying urban residents as hapless, helpless victims. The notion of experiments provides avenues to explore alternative ways to engage creatively with the generation of climate change action in unexpected places.

The case also highlights that our knowledge of potential spaces of action beyond the spheres of government is very limited, not only in terms of understanding which actors are better suited to provide effective climate change responses but also in terms of knowing who are those actors and what is their current role in urban environmental governance. This also points out that although climate change action should meet these two conditions, these are not sufficient to ensure that such action is socially and environmentally just. Little is known yet about the unintended consequences of current actions for climate change and even less about the emerging rationalities which climate action may lead to. This should not deter action, however, because transformative ideas always have implicit risks, but it should pose a warning on normative and uncritical approaches to climate change action.

\section{Acknowledgements}

The authors wish to acknowledge the support from the following individuals: Ralf Tuts, Harriet Bulkeley, Jonathan Silver, Julio Davila, Yves Cabannes, Colin Hagans, Emily Boyd and Jonathan Ensor. The authors would also like to thank personnel at the Fundo National do Ambiente (FUNAB) in Mozambique and, in particular, the collaboration and insights from Carlos Seventine. 
Part of the work in this paper was supported by the Climate Development Knowledge Network. A disclaimer applies. Figures 1-3 and Tables 1, 2, 5 and 6 have been adapted from Junior, P. and Spaliviero, M., 2009. Climate change impacts in urban areas of Mozambique a pilot initiative in Maputo city, SUD-Net Cities and Climate Change Initiative (CCCI) [online]. Maputo: UN-Habitat. Available from: http://www.unhabitat.org/downloads/docs/10406_1_594151.pdf [Accessed 20 May 2013].

\section{Note}

1. Developed by the Oxford Poverty and Human Development Initiative (OPHI) for the United Nations Development Programme's flagship Human Development Report.

\section{References}

ActionAid, 2006. Climate change, urban flooding and the rights of the urban poor in Africa. Key findings from six African cities: Nairobi, Kenya; Kampala, Uganda; Lagos, Nigeria; Accra, Ghana; Freetown, Sierra Leone and Maputo, Mozambique. Johannesburg: ActionAid Available from: http://www.actionaid.org/docs/urban flooding africa report.pdf [Accessed 25 February 2012].

Alkire, S., et al., 2011a. Multidimensional Poverty Index: 2011 data. Oxford: Poverty and Human Development Initiative.

Alkire, S., et al., 2011b. Mozambique country briefing [online]. Oxford: Poverty \& Human Development Initiative (OPHI). Multidimensional Poverty Index Country Briefing Series. Available from: www.ophi.org.uk/policy/multidimensional-poverty-index/mpi-country-briefings [Accessed 25 February 2012].

Betsill, M. and Bulkeley, H., 2007. Looking back and thinking ahead: a decade of Cities and Climate Change Research. Local Environment: The International Journal of Justice and Sustainability, $12(5), 447-456$.

Biermann, F. and Pattberg, P., 2008. Global environmental governance: taking stock, moving forward. Annual Review of Environment and Resources, 33 (1), 277-294.

Blaikie, P. and Brookfield, H., 1987. Land degradation and society. London: Methuen and Co, Ltd.

Brown, H. and Vergragt, P., 2008. Bounded socio-technical experiments as agents of systemic change: the case of a zero-energy residential building. Technological Forecasting \& Social Change, 75 (1), $107-130$.

Brück, T. and Broeck, K.V.d., 2005. Growth, employment and poverty in Mozambique. Berlin: International Labour Organization.

Bulkeley, H., 2010. Cities and the governing of climate change. Annual Review of Environment and Resources, 35, 229-253.

Bulkeley, H. and Betsill, M.M., 2003. Cities and climate change: urban sustainability and global environmental governance. Oxon, NY: Routledge.

Bulkeley, H. and Castan Broto, V., 2013. Government by experiment? Global cities and the governing of climate change. Transactions of the Institute of British Geographers. Advance online publication, doi:10.1111/j.1475-5661.2012.00535.x.

Bulkeley, H. and Kern, K., 2006. Local government and the governing of climate change in Germany and the UK. Urban Studies, 43 (12), 2237-2259.

Bulkeley, H., et al., 2009. Cities and climate change: the role of institutions, governance and urban planning. World Bank Urban Research symposium cities and climate change. Marseille: World Bank.

Bulkeley, H., et al., 2011. Cities and low carbon transitions. London: Routledge.

Davies, A.R., 2005. Local action for climate change: transnational networks and the Irish experience. Local Environment: The International Journal of Justice and Sustainability, 10 (1), 21-40.

Desfor, G. and Keil, R., 2004. Nature and the city: making environmental policy in Toronto and Los Angeles. Tucson: The University of Arizona Press.

Doan, P. and Oduro, C.Y., 2011. Patterns of population growth in peri-urban Accra, Ghana. International Journal of Urban and Regional Research, 36 (6), 1306-1325.

Folke, C., et al., 2002. Resilience and sustainable development: building adaptive capacity in a world of transformations. AMBIO: A Journal of the Human Environment, 31 (5), 437-440. 
Forsyth, T., 2003. Critical political ecology: the politics of environmental science. Oxon, NY: Routledge.

Forsyth, T., 2005. Enhancing climate technology transfer through greater public-private cooperation: lessons from Thailand and the Philippines. Natural Resources Forum, 29 (2), 165-176.

Forsyth, T., 2007. Promoting the "Development Dividend" of climate technology transfer: can cross-sector partnerships help? World Development, 35 (10), 1684-1698.

Glasbergen, P., 1998. Co-operative environmental governance: public-private agreements as a policy strategy. Dordrecht: Kluwer Academic Publishers.

Graham, S. and Healey, P., 1999. Relational concepts of space and place: issues for planning theory and practice. European Planning Studies, 7 (5), 623-646.

Heynen, N.C., Kaika, M., and Swyngedouw, E., 2006. In the nature of cities: urban political ecology and the politics of urban metabolism. Oxon, NY: Routledge.

Hoffman, M., 2011. Climate governance at the crossroads: experimenting with a global response after Kyoto. Oxford: Oxford University Press.

INE, 2012. Definitive data of the 2007 3rd population and habitation census of Mozambique. Maputo: Instituto Nacional de Estadistica.

IPCC, 2007. Climate change 2007: mitigation of climate change. Contribution of Working Group III to the Fourth Assessment Report of the Intergovernmental Panel on Climate Change, 2007 [B. Metz, O.R. Davidson, P.R. Bosch, R. Dave, L.A. Meyer (Eds.)]. Cambridge and New York: Cambridge University Press.

Jasanoff, S., 2006. Transparency in public science: purposes, reasons, limits. Law and Contemporary Problems, 69 (3), 21-45.

Kaika, M., 2006. City of flows: modernity, nature and the city. Oxon, NY: Routledge.

Kern, K. and Alber, G., 2008. Governing climate change in cities: modes of urban climate governance in multi-level systems. Proceedings of the OECD conference on "Competitive cities and climate change". Paris: OECD.

Kern, K. and Bulkeley, H., 2009. Cities, Europeanization and multi-level governance: governing climate change through transnational municipal networks. JCMS: Journal of Common Market Studies, 47 (2), 309-332.

Kundzewicz, Z.W., et al., 2002. Floods and droughts: coping with variability and climate change. Natural Resources Forum, 26, 263-274.

Latour, B., 1993. We have never been modern. Hampstead: Harvester Wheatsheaf.

Latour, B., 2005. Reassembling the social: an introduction to actor-network-theory. Oxford: Oxford University Press.

Lorenzoni, I., Nicholson-Cole, S., and Whitmarsh, L., 2007. Barriers perceived to engaging with climate change among the UK public and their policy implications. Global Environmental Change, 17 (3-4), 445-459.

McBean, G. and Henstra, D., 2003. Climate change, natural hazards and cities. Research Paper Series no. 31. Toronto: Institute for Catastrophic Loss Reduction (ICLR).

MICOA, 2007. National Adaptation Program of Action (NAPA). Maputo: Government of Mozambique. Available from: http://unfccc.int/resource/docs/napa/moz01.pdf [Accessed 20 May 2013].

Mieg, H.A., 2012. Sustainability and innovation in urban development: concept and case. Sustainable Development, 20 (4), 251-263.

MMC, UN-Habitat, and Agriconsulting, 2012. Availação detalhada dos impactos resultantes dos eventos das mudanças climáticas no Município de Maputo. Nairobi: UN-Habitat.

Mussa, A., et al., 2003. Late Weichselian to Holocene evolution of the Maputo Bay, Mozambique. XVI International Union for Quaternary Research (INQUA) Congress. Reno, NV: INQUA.

Peet, R., Robbins, P. and Watts, M., eds., 2011. Global political ecology. Oxon, NY: Routledge.

Plummer, R. and FitzGibbon, J., 2004. Some observations on the terminology in co-operative environmental management. Journal of Environmental Management, 70 (1), 63-72.

Robinson, J., 2006. Ordinary cities: between modernity and development. London: Routledge.

Romero Lankao, P., 2007. How do local governments in Mexico City manage global warming? Local Environment: The International Journal of Justice and Sustainability, 12 (5), 519-535.

Sidaway, J.D. and Power, M., 1995. Sociospatial transformations in the "postsocialist" periphery: the case of Maputo, Mozambique. Environment and Planning A, 27 (9), 1463-1491.

Simone, A., 2010. City life from Jakarta to Dakar: movements at the crossroads. NY: Routledge. 
Smit, B. and Wandel, J., 2006. Adaptation, adaptive capacity and vulnerability. Global Environmental Change, 16 (3), 282-292.

Swyngedouw, E., 2004. Social power and the urbanization of water - flows of power. Oxford: Oxford University Press.

Thow, A. and de Blois, M., 2008. Climate change and human vulnerability: mapping emerging trends and risk hotspots for humanitarian actors. CARE Discussion Paper Geneva: CARE.

UNDESA, 2007. World urbanization prospects: the 2007 revision. NY: United Nations Department of Economic and Social Affairs, Population Division.

UNDP, 2007. Mozambique human development report. Maputo: United Nations Development Programme.

WB, 2009. Municipal development in Mozambique: lessons from the first decade. Washington: World Bank.

WB, 2010. Cities and climate change: an urgent agenda. Washington, DC: World Bank. 